\title{
Establishment of National Legislation of the State of the Democratic Republic of Timor-Leste in Accordance with the Legal Ideals in the Constitution of 2002
}

\author{
Leonito Ribeiro \\ Students of Udayana University's Doctoral Law Program \\ Email: leonito.ribeiro@gmail.com
}

\begin{abstract}
The writing of this Dissertation, examines the "Establishment of National Legislation of the State of the Democratic Republic of Timor-Leste in accordance with the Legal Ideals in the Constitution of 2002". Which outlines the issues of statehood in the State of Timor-Leste, The establishment of legislation is essentially aimed at realizing legal certainty and justice in accordance with the legal mind (rechtsidee). The legal ideal as stated in the opening of the RDTL constitution in 2002. The establishment of the RDTL State Legislation is derived from the provisions of Article 1 paragraph (1) and Article 2 paragraph (2) of the RDTL Constitution of 2002. It explicitly states that Timor-Leste is a State of Law and Democracy, thus resolving legal issues by ensuring legal certainty to the public. And produce views / thoughts in order to produce laws that guarantee legal certainty. In Timor-Leste there is no hierarchy of legal norms, so there is a conflict of norms vertically and horizontal, besides not yet a philosophy of the nation that can be used as a source of all legal sources, and also the absence of a National Legislative Body to produce a good and responsive legislation. There are formulated three There are formulated three main formulations of the problem, namely: (1) The Essence of the Establishment of National Legislation of the Democratic Republic of Timor-Leste related to the Legal Mind in the Constitution of 2002. (2) Establishment of National Legislation of the State of the Democratic Republic of Timor-Leste related to the Ideal of Law. (3) Criteria of Laws and Regulations under the Responsive Act. Of the three problems presented, the general objective to be achieved is to study and understand analyzing the Establishment of National Legislation of the Democratic Republic of Timor-Leste from the philosophical and philosophical perspective of the Timor-Leste nation, which is in accordance with theoretical conceptual thinking based on the 2002 Constitution, and to analyze the Criteria of Legislation / Regulations under a responsive Law. This research includes a type of normative legal research, with a statutory approach, a conceptual approach, a comparative approach and a historical approach. The legal materials used are primary legal materials, secondary legal materials and tertiary legal materials. This research yielded several conclusions, namely, the Essence of the Establishment of National Legislature in Timor-Leste related to the Legal Mind (recht idee) then can use the Philosophy of Uma Lulik, as a basic norm (Groundnorm) and legal ideal, can be used as a basis, source and guideline or philosophy of Uma Lulik as the source of all legal sources, must be spelled out in the laws and regulations of the State of the Democratic Republic of Timor-Leste. The two Timor-Leste do not yet have Hierarchy of Legal Norms which so there is still a conflict of norms both vertical and horizontal, thus the need for a Hierarchy of Legal Norms to avoid legal disputes. The three good laws and regulations are laws and regulations whose contents meet the expectations of the affected communities with laws and regulations that ensure legal certainty and justice, the need for the role of the National Legislation Agency in Timor-Leste, fourth, using ROCCIPI approach in designing a law.
\end{abstract}

Keywords: Legislation, The Mind of the Law, philosophy of the nation.

DOI: $10.7176 / \mathrm{JLPG} / 118-10$

Publication date: February $28^{\text {th }} 2022$

\section{Preliminary}

\subsection{Backround}

In the provisions of the positive law on the legislation of the Democratic Republic of Timor-Leste, namely the 2002 RDTL Constitution and the relevant legislation in outlining the establishment of theoretically and philosophically justified legislation, which contains the values of the nation's struggle that contain the essence of the state's objectives.

The legal ideal (rechtsidee) of the RDTL state is reflected in the expectations of the nation contained in the objectives of the state, so that in order to implement all aspects of development always uphold the values of justice and legal certainty. The implementation of development in all its aspects and the implementation of the government of the RDTL state, must always be based on the idea of a democratic state based on legal sovereignty.

In line with the provisions of Article 1 (paragraph 1) of the RDTL Constitution of 2002 mentions :

A República Democrático de Timor-Leste é um Estado de direito democrático, soberano, independente 
e unitário, baseado na vontade popular e no respeito pela dignidade da pessoa humana. ${ }^{1}$ (Translate "The Democratic Republic of East Timor is a democratic, sovereign, independent and unitary State based on the rule of law, the will of the people and the respect for the dignity of the human person". ${ }^{2}$ (Tetum Translate : República Democrático de Timor-Leste Estadu tuir-lei no tuir-demokrasia, Soberanu, independente no unitátriu ida, ne'ebé hatuur iha povu nia vontade no iha respeitu ba ema nia dignidade). ${ }^{3}$

"The Democratic Republic of Timor-Leste is a democratic, sovereign, independent and united State of Law, based on the power of law, the will of the people and the honor of human dignity". The legal ideal as stated in the opening of the RDTL constitution of 2002 as a philosophical justification.

While sociological justification relates to the demands of public expectations that want amendments to the 2002 RDTL Constitution to change the provisions of its legal norms and fill the legal vacuum in producing responsive laws and regulations in accordance with community expectations. In justification of the juridical aspect in this research, it produces views / thoughts in order to produce laws that guarantee legal certainty.

A State may be classed as a State of law (Rechtsstaat) according to Burkens, if it meets the conditions:

1. The principle of legality, every act of government must be based on laws and regulations (wettelijke grenslag). With this foundation, the law in the sense of formil and the Constitution itself is the basis of the policy of not government. In this relationship, the establishment of the Act constitutes an important part of the state of law.

2. Division of power, this condition means that state power should not rest on only one hand.

3. Basic rights (grondrechten) are the target of protection from the government against the people and at the same time limit the power of the establishment of the Law.

4. Judicial supervision for the people is available through a free trial to test the validity of the act of government "rechtmaticgeheid stoetsing".4

Thus, the rule of law means that in the administration of government and development, both the government apparatus and every citizen must submit to the law. The principle of legality / rule of law is closely related to legal politics, especially the formation of legislation. The establishment of legislation should be successful and useful for the welfare of the people, according to the type of modern legal state.

The type of modern legal state or known as the mention of the state of material law, means that the state interferes as widely as possible in all activities of society to realize the general welfare". However, efforts to achieve the realization of the general welfare, should be accompanied by the politics of national legislation of the DPRTL State that is well organized by siding with the public interest and the creation of a democratic State government based on supremacy. law.

The establishment of the National Legislation of the RDTL State is derived from the provisions of Article 1 paragraph (1) and Article 2 paragraph (2) of the RDTL Constitution of 2002. Article 1 paragraph (1) of the RDTL Constitution of 2002 specifies:

A República Democrático de Timor-Leste é um Estado de direito democrático, soberano, independente e unitário, baseado na vontade popular e no respeito pela dignidade da pessoa humana. (english Language) "The Democratic Republic of East Timor is a democratic, sovereign, independent and unitary State based on the rule of law, the will of the people and the respect for the dignity of the human person". 5

In Tetum Language :

República Democrático de Timor-Leste Estadu tuir-lei no tuir-demokrasia, Soberanu, independente no unitátriu ida, ne'ebé hatuur iha povu nia vontade no iha respeitu ba ema nia dignidade. ( "Republic of Democrtic Timor-Leste are democratic state.

By law, it is sovereign, independent and united, based on the general will of the people and the honor of human dignity." And in Article 2 paragraph (2) of the RDTL Constitution of 2002 determines

$\mathrm{O}$ estado subordina-se á Constituicão e ás leis" ${ }^{6}$ (Bahasa inggris : The State shall be subject to the Constitution and to the law". ${ }^{7}$ Bahasa Tetum : Estadu tuur iha Konstituisaun no Lei nia okos". ${ }^{8}$

Consequently, if the state of Timor-Leste does not have a law on the hierarchy of norms that is certain then the impact on the state and society, consequences for the state for example, there is no clear legal basis, making it difficult for the government to take policy, then the opportunity for abuse of authority cannot be

${ }^{1}$ Constituicão da República Democrático de Timor-Leste, ano 2002.p.10

${ }^{2}$ Constitution of The Democratic Republic of East Timor, UNDP-Timor-Leste p.11

${ }^{3}$ Constituicão Anotada República Democrático de Timor-Leste, Empresa Diário do Minho, Lda, Braga, Portugal, p.19

${ }^{4}$ Abdul Kadir Besar.1995. Implementation of The Ideal of Law and Application of The Principles of National Law Since New Order. National Law Magazine. Special Edition of 50 Years of National Development. . In https://media.neliti.com/media/publications/84430-IDperanah-cita-hukum-dalam-pembentukan-huk.pdf, accessed on 17 April 2021 at 22, 45 Timor-Leste Time.

${ }^{5}$ Constituicão Anotada República Democrático de Timor-Leste, Empresa Diário do Minho, Lda, Braga, Portugal,

${ }^{6}$ Constituicão Anotada República..Op.Cit .p.19

${ }^{7}$ Constituicão da República ..Op.Cit . p.10

${ }^{8}$ Constitution of The Democratic Republic... Op.Cit.p.12 
avoided, while the consequences for society for example, the lack of human rights of the people, so that the opportunity for violations of human rights is inevitable. People are very open.

Many other causes that arise such as the first, possible problems due to the present (in the State of TimorLeste), there has been no Establishment of National Legislation In Accordance with the Legal Mind in the RDTL Constitution of 2002. The second problem, namely, since the State of Timor-Leste proclaimed the recognition of its independence in 2002 until now, there has not been established a philosophy of the nation that is used as the ideology of the State.

The third problem, also that is still faced in the RDTL Country, namely, because of the ability of professional Human Resources (HR) in the formation of legislation. Problem four, which is faced in the RDTL Country, namely, because there is no Policy on the Establishment of Legislation that contains the stages of the formation of laws and regulations as is the case in Indonesia in accordance with Law No. 12 of 2011 concerning the Establishment of Laws and Regulations.

In addition to the problem of the absence of The Hierarchy of Norms Law in Timor-Leste also The absence of Institutions or Commissions, the National Legislation Agency is specifically to produce good and responsive legislation products, as a result of which the Government has not been able to create a Policy of Law Formation that contains the stages of the formation of good laws and regulations, has not been able to create content material in government regulations with clear reference. And also legslation bodies can also function to synchronize and harmonize laws and regulations so that there is no overlap of legal norms.

\subsection{Legal Issue}

From the description above, there are problems that will be formulated in this article, among others:

1. What is the essence of the Establishment of National Legislation of the State of the Democratic Republic of Timor-Leste related to the Legal Ideals in the Constitution of 2002 ?

2. How is kreteria establishment of a good and responsive National Legislation of the Democratic Republic of Timor-Leste?

\subsection{Research Methods}

The research used in this study is normative legal research, namely by collecting primary legal materials, secondary legal materials and tertiary legal materials, to obtain normative juridical understanding equipped with theoretical justifications for clarification and academic justification related to the subject matter. The approach used in analyzing the proposed problems is the approach of legislation, concepts, comparisons, and history.

\subsection{Discussion}

\subsubsection{Philosophical and Theoretical Thought Related to the Establishment of National Legislation of the State of the Democratic Republic of Timor Leste. \\ 1.4.11 Philosophy of Uma Lulik}

Since the Democratic Republic of Timor-Leste, proclaimed on November 28, 1975, was restored to independence in 2002, all aspects of development including the development of law, especially policy in the field of legislation. In relation to the politics of legislation, it may be necessary to consider the use of the fhilosphy of Uma Lulik as the philosophy of the East Timorese nation which later served as the basis and ideology of the State.

The philosophy of Uma-Lulik can be studied from four perspectives, namely, philosophical, sociological, juridical and etymological perspectives. Etymologically Uma means House and Lulik means Holy/ Holy / Sacred. Thus, literally Uma Lulik means "Holy House". With Uma Lulik every citizen of the Democratic Republic of Timor-Leste can find out his social status, derived from noble ancestry or not. "The philosophy of Uma-Lulik can be viewed as a noble agreement that unites all tribal ties into one nation that is compound in the principle of unity, every Timor-Leste man, from the western end of Oecusse to the Eastern end of Tutuala, must have Uma Lulik. Uma Lulik is a philosophical symbol of the general union and relationship of man, man and man with nature and man with ancestors or ancestors, which is still maintained from time immemorial until now."1

Dotted from the opinion can be drawn philosophical elements Uma Lulik as follows: elements of religiomagis (Divinity) a sublime deal family/unity elements elements of humanity environment/human with nature customs Deliberation (democracy) Help/welfare. For Timor-Leste society, if a person does not have Uma Lulik will be categorized as an Immigrant (lemorai, laorai) and a person who has no roots, or does not have a clear hereditary policy (origin).

\footnotetext{
${ }^{1}$ Constitution of The Democratic Republic of East Timor, UNDP-Timor-Leste
} 
Photo 1. Homes of various Municipiu/Municipalities).

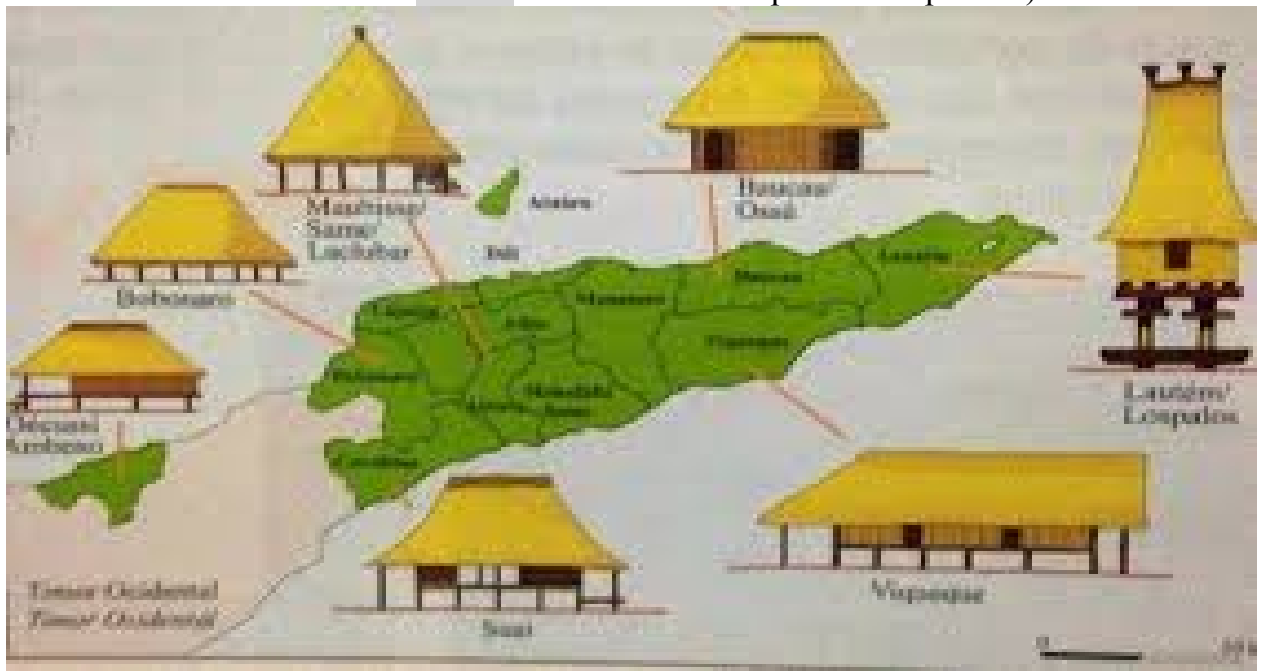

The philosophy of Uma-Lulik is also perceived as a place of worship to the ancestors of his descendants. In the Mambae tribe "the person who does not have the traditional house, is said to be a person who does not have a clear identity, with the figurative word in the Mambae Suco Rotuto language "Mou Man Hiut, Lau Man Lei". So the point is that every Timor-Leste has Uma Lulik, for example: Suco Adat Bunak (Marae), is in Bobonaro Uma Lulik by name, Uma-Lulik Tae-Bele, Lokhal-Giral, Leo-Hilin, Námau, Suco Adat Makasae in Baucau there, Uma Lulik Boleha, Suco Adat Mambae Ainaro there Uma-Lulik Bessmau-Daskoli, Suco Adat Tetun-Terik in Kovalima Ada Uma Lulik Babulo, Loro, in Viqueque there is Uma Lulik Uma'in, Kaiwa, Wairini, Dikurhun, Hae-Ura.

Uma Lulik from a Philosophical point of view, Uma-Lulik is the basis of people's beliefs about the things that are aspired to, sacred or sacred places and Religiomagis (the existence of God), as a symbol or motaphoric and high spiritual bond and is actually the basis for the organization of the state crystallized from the values of Uma-Lulik, as hone and ospina reveal that:

Uma Lulik ne'e maka uma sagradu ida (fatin lolos ida) no "uma sagrada" simboliku/motaforika ho sintidu ispiritual boot no uma familia individual ida nian iha mundu. Membru komunidade no grupu solidaridade hetan fasilitasaun liuhusi Uma Lulik no indentifikasaun husi ema ida-nia familia tutan. Familia hahu ho uma kain, ne'ebe pretense ba knua boot liu ida ka suco. Suco hirak kontrariamente iha asosiasaun ho Uma Lulik ida, uma sagradu ida ne'be fungsiona nu'udar baze/sentru ba nivel oi-oin (multiplayer) husi familia tutan"( translate in English)

Uma-Lulik is a holy house (proper place) and a "sacred house," a symbol of strong spiritual bonds and a family home of the world's individuals. Members of the community and solidarity groups get facilities through Uma Lulik and identify each person's genealogy. A family develops through small households that are part of a village or tribe. However, in some Suco there are several Uma Lulik, and in Uma Lulik there are several levels as follows: Uma Kain, Uma Fukun and Uma Lulik the largest.

The philosophy of Uma lulik which contains important elements that can be used as a foundation in the life of society and state. These elements include, elements of religiomagis (Divinity), noble agreement, elements of family / unity. In addition, it contains the philosophy of the human element or elements of human rights, the environment / human with nature, customs, deliberation (democracy) and elements of help / welfare. From the above description it can be concluded that the essence of the Establishment of National Legislature in TimorLeste related to the Legal Mind (rech idee) can then use the Philosophy of Uma Lulik, as a basic norm (Groundnorm) and legal ideal, can be used as a basis, source and guideline or Philosophy of Uma Lulik as the source of all legal sources, must be spelled out in the laws and regulations of the Democratic Republic of TimorLeste.

\subsubsection{Criteria for Good or Responsive Laws and Regulations.}

Good laws and regulations in this section, according to the author as a form of legislation whose content meets the expectations of the people affected by the legislation because the contents guarantee legal certainty and justice "Understanding of philosophical, sociological, and juridical foundations as noted ByVia Hasanah, that always contained in the main mind on the consideration of a regulation essentially serves as a considerations and reasons for its formation whose writings are placed sequentially from philosophical, sociological, and juridical. Philosophical elements are interpreted as considerations or reasons that illustrate that the regulations formed consider the outlook on life, awareness, and legal ideals that include the atmosphere of kebatinan and philosophy of the Indonesian nation derived from Pancasila and the Opening of the Constitution of the Republic 
of Indonesia in 1945.

The sociological foundation actually concerns empirical facts about the development of problems and needs of society and the state. Then the juridical element illustrates that regulations are formed to overcome legal problems or fill legal gaps taking into account existing rules, which will be changed, or that will be repealed to ensure legal certainty and a sense of community justice."

To produce a good rule of law requires careful philosophical, sociological and juridical considerations. Technical personnel not only master the technique of problems, arrangement, systematic legal language, but also must know the basics as follows: The purpose of the establishment must be clear or the product of the Law has a target that will be achieved / can regulate an irregular society into an orderly society.

The establishment of good laws and regulations in order to produce responsive national laws, then it can only be realized if supported by a method of formation that is systemistic and careful. The RDTL State which is a demokartis State, has the authority and constitutional and juridical obligations to carry out good national legal development, which is carried out in a planned, integrated, and sustainable manner in a programmatically structured national legal system.

Therefore, in the establishment of the national law of the RDTL State, the drafters of the Act, the legislators of the National Parliament, the civil servants whose work is related to the formation of legislation. In carrying out its duties and funksis must master the principles and foundations of laws and regulations as a basis for determining attitudes and in the formation of laws and regulations. "Good laws and regulations must promote the principle of human rights protection. (fundamental human rights) as required in the concept of a state of law."

The establishment of good laws and regulations by the designers will be an important reference (guideline) how to produce legal products in the form of laws and regulations that are in accordance with public needs. On the other hand, planning that is not guided by these principles will result in laws and regulations that are difficult to implement because of vague legal norms and conflicts of norms. Therefore, normative understanding of legal theories, concepts and principles is very important in the formation of regulations, thus implementing responsive laws and regulations.

In order to create harmonization and synchronization in the establishment of laws and regulations, for the role of the players, there is an understanding of legal principles such as, the principle of legal preverence which includes, the principle of Lex Superior Derogat Legi Inferiori, Lex Special Derogaat Legi Generali and Lex Posterior Derogat Legi Priori.

Thus it can be concluded that a good legislation is a law that meets the expectations of the affected community with laws and regulations that ensure legal certainty and justice, the need for the role of the National Legislation Agency in Timor-Leste.

\subsection{Conclusion}

Based on the discussion that has been outlined earlier, it can be concluded as follows:

1. The establishment of a National Legislature in Timor-Leste related to the legal ideal (rech idee) can then use the Philosophy of Uma Lulik, as a basic norm (Groundnorm) and legal ideal, can be used as a basis, source and guideline or philosophy of Uma Lulik as the source of all legal sources, must be spelled out in the laws and regulations of the State of the Democratic Republic of Timor-Leste.

2. A good law is a law that meets the expectations of the affected community with laws and regulations that ensure legal certainty and justice, the need for the role of the National Legislation Agency in Timor-Leste.

\section{Reference}

A.V. Dicey, 1987, Introduction To The Study of The Law of The Constitution, Fifth edition, London Macmillan and Co., Limited New York: The Macmillan Company.

Abdul Kadir Besar.1995. Implementation of The Ideal of Law and Application of The Principles of National Law Since New Order. National Law Magazine. Special Edition of 50 Years of National Development. . In https://media.neliti.com/media/publications/84430-ID-peranah-cita-hukum-dalam-pembentukan-huk.pdf, accessed on 17 April 2021 at 22, 45 Timor-Leste Time.

Constituicão da República Democrático de Timor-Leste, ano 2002.

Constituicão Anotada República Democrático de Timor-Leste, Empresa Diário do Minho, Lda, Braga, Portugal, Constitution of The Democratic Republic of East Timor, UNDP-Timor-Leste

J.J.H Bruggink, 1996, Reflections on the Law, Arief Sidharta, Aditya Bhakti Image

Konstitusi Republik Demokratik Timor-Leste Tahun 2002.UNDP-Timor-Leste.

Oka Mahendra. "The process of establishing the Legal Ideal and Applying the Principles of National Law Now and in the Future." National Law Magazine. Special Edition of 50 Years of National Development 1995. in https://media.neliti.com/media/publications/84430-ID-peranah-cita-hukum-dalam-pembentukan-huk.pdf, accessed 17 April 2021 at 22, 45 Timor-Leste Time.

Peter Mahmud Marzuki,2016, Legal Research, revised edition, Kencana Prenada Media 
Ridwan HR., 2006, State Administrative Law, PT. King Grafindo Persada, Jakarta,

Riri Nazriyah, The Role of Legal Minds in the Formation of National Law, Article in JURNAL HUKUM. NO. 20 VOL. 9. JUNE $2002: 136$ - 151 accessed inhttps://media.neliti.com/media/publications/84430-ID-peranahcita-hukum-dalam-pembentukan-huk.pdf, access on February 13, 2022, at 11:20 am.

Ruslan Abdul Gani." The Process of Formulating Legal Ideals and Principles of H ukum in the Period 19081945 (Historical-Empirical and Analytical-Analytical Approach)." National Law Magazine. Special Edition of 50 Years of National Development. in https://media.neliti.com/media/publications/84430-ID-peranahcita-hukum-dalam-pembentukan-huk.pdf, accessed on 17 April 2021 at 22, 45 Timor-Leste Time.

Ruslan Saleh, "The Construction of The Ideal of Law and the Application of The Principles of National Law." National Law Magazine. Special edition of 50 Years of National Development 11995 P.49 in https://media.neliti.com/media/publications/84430-ID-peranah-cita-hukum-dalam-pembentukan-huk.pdf, accessed 17 April 2021 at 22.45 Timor-Leste Time.

Teguh Prasetyo and Abdul Hakim Barkatullah, 2005, Political Criminal Law (Criminalization and Decriminalization Policy Review), Student Library, Jogyakarta,

John Usfunan, 1985, Aspects of State Defense Law in Indonesia, Ayu Sarana Cerdas Denpasar, hereinafter called John Usfunan II.

John Usfunan, 2004, noted the views, Burken M.C., et.al., (Beginselen van de Democratiche Rechtstaat, Tjeenk Willink Zwole, 1990, p.29), Scientific Oration, Design of Good Invitations To Create a Clean And Democratic Government, Inaugural Speech of Professorship of The Faculty of Law Unud, May 1, 2004,

John Usfunan, 2007, Politics of Legislation in the Transitional State of Timor Leste, Scientific Oration, In the Graduation ceremony of Bachelor of Force I Da Paz Dili University of Timor Leste, October 24, 2007, hereinafter called John Usfunan III.

John Usfunan, 2015, Political Human Rights (Freedom of Opinion in Idonesia). Udayana 